\title{
Pengaruh saluran distribusi, keunggulan produk, dan persediaan produk, melalui keputusan pembelian pada PT. Tasya Gasindo Medan
}

\author{
Annes Munte; Hendra Jonathan Sibarani* \\ Jurusan Manajemen Pemasaran, Fakultas Ekonomi, Universitas Prima Indonesia \\ *E-mail korespodensi: hendrajonathansibarani@unprimdn.ac.id
}

\begin{abstract}
Natural gas is used by the public because it is more efficient and cheaper than others. but the $3 \mathrm{~kg}$ gas cylinder often leaks, the weight of the gas cylinder is not as expected, then the $3 \mathrm{~kg}$ gas cylinder is often empty of stock. this study aims to determine the effect of distribution channels, product advantages, and product supplies through purchasing decisions. This type of research uses descriptive research. The research aims to determine the effect of distribution channels, product advantages, and product supplies through purchasing decisions. The population in the company as many as 70 and taken 30 populations from similar companies so that the population amounted to 100, the number of samples studied in this study were 100 samples. The study used multiple linear analysis shows distribution channels, product advantages, and product supplies effect positive and significant to purchasing decisions. The t-test of the distribution channel obtained $t_{\text {count }}<t_{\text {table }}$ the sig value $F_{\text {count }}>F_{\text {table }}$ means that the distribution channel has no effect and is not significant towards purchasing decisions, product excellence is obtained $t_{\text {count }}>t_{\text {table }}$ then the sig value $F_{\text {count }}<F_{\text {table }}$ means that product excellence has a significant effect on purchasing decisions, and value product inventory obtained $t_{\text {count }}>t_{\text {table }}$ then the sig value $F_{\text {count }}<F_{\text {table }}$ means that product inventory has a significant effect on purchasing decisions.
\end{abstract}

Keywords: Distribution channels, Product advantages, Product inventory, Buying decision

\begin{abstract}
Abstrak
Bahan bakar gas digunakan oleh masyarakat karena efisien, dan murah dibandingkan yang lain, tetapi tabung gas $3 \mathrm{~kg}$ sering mengalami kebocoran, berat tabung gas tidak sesuai yang diharapkan, kemudian tabung gas $3 \mathrm{~kg}$ sering mengalami kosong stock, Penelitian bertujuan untuk mengetahui pengaruh saluran distribusi, keunggulan produk, dan persediaan produk melalui keputusan pembelian. Populasi pada perusahaan sebanyak 70 dan diambil 30 populasi dari perusahaan sejenis sehingga populasi berjumlah 100, Jumlah sampel yang diteliti dalam penelitian sebanyak 100 sampel. Penelitian menggunakan analisis linier berganda menunjukan saluran distribusi, keunggulan produk, persedian produk, berpengaruh positif dan signifikan terhadap keputusan pembelian. Uji $t$ dari saluran distribusi diperoleh $t_{\text {hitung }}<t_{\text {tabel}}$, nilai sig $f_{\text {hitung }}>f_{\text {tabel }}$ artinya Saluran Distribusi tidak berpengaruh dan tidak signifikan terhadap Keputusan Pembelian, keunggulan produk diperoleh $t_{\text {hitung }}>t_{\text {tabel }}$ kemudian nilai sig $\mathrm{f}_{\text {hitung }}<\mathrm{f}_{\text {tabel }}$ artinya Keunggulan produk berpengaruh signifikan terhadap Keputusan Pembelian, dan nilai persediaan produk diperoleh $t_{\text {hitung }}>t_{\text {tabel }}$ kemudian nilai sig $\mathrm{f}_{\text {hitung }}<\mathrm{f}_{\text {tabel }}$ artinya persediaan produk berpengaruh signifikan terhadap Keputusan Pembelian.
\end{abstract}

Kata kunci: Saluran distribusi, Keunggulan produk, Persediaan produk, Keputusan pembelian 


\section{PENDAHULUAN}

Dalam era modern saat ini, persaingan dalam dunia bisnis semakin ketat, dan berkembang pesat. Karena, setiap perusahaan menginginkan perusahaannya lebih unggul dari kompetitornya dengan cara membuat perencanaan strategi yang baik demi mendapatkan kepercayaan dan pencitraan yang positif dari konsumen. Bisnis merupakan suatu kegiatan atau usaha yang dilakukan oleh seseorang atau kelompok. Oleh karenanya, setiap kegiatan bisnis telah muncul sejak dulu. Dunia bisnis lebih kompleks, dan lebih menuntut tanggung jawab. Bisnis menciptakan banyak peluang berdasarkan kreativitas dan inovasi yang ditampilkan dengan melibatkan beberapa, puluhan, ratusan, bahkan ribuan orang untuk menghasilkan atau menyalurkan produk atau jasa yang dibutuhkan konsumen.

Tidak hanya itu, persaingan bisnis bukan hanya terjadi antar perusahaan saja tetapi dapat juga terjadi persaingan diantara rantai pemasok. Hal ini berarti menajemen operasi perlu diperbaharui oleh perusahaan kepada mitra-mitra bisnisnya, seperti pemasok, distributor, dan lain-lain. dalam perkembangan selanjutnya manajemen operasi harus cukup fokus pada satu faktor kinerja kompetitif operasi seperti ongkos produksi rendah dan kualitas, flesibilitas, kecepatan, keandalan dan biaya

PT. Tasya Gasindo adalah salah satu perusahan swasta yang menjadi agen gas LPG $3 \mathrm{Kg}$ yang beralamat di Jalan Karya No 218 kelurahan karang berombak kecamatan medan barat. Perusahaan ini bergerak dalam pendistribusian gas bersubsidi kepada masyarakat, PT. Tasya Gasindo berdiri sejak tahun 2010 dan telah bekerjasama dengan pertamina dalam mendistribusikan gas bersubsidi.

Salah satu kebutuhan masyarakat saat ini yang wajib dimiliki dan paling dicari adalah LPG (liquefied natural gas). Di era modern saat ini bahan bakar gas banyak digunakan oleh masyarakat karena lebih efisien, murah dan hemat waktu dibandingkan dengan bahan bakar yang lainnya. Karena besarnya minat masyarakat yang menggunakan gas LPG sehingga membuat pengusahan memberanikan diri menjadi agen gas dan mempermudah masyarakat untuk mendapatkan, menggunakan dan tanpa rasa khawatir mendapatkan gas LPG oplosan karena agen mendapat gas LPG langsung dari Pertamina salah satu Badan Usaha Milik Negara. Namun dengan begitu rasa khawatir masyarat selalu ada terhadap tabung gas LPG $3 \mathrm{~kg}$ yang disubsidi oleh pemerintah dikarenakan kejadian gas LPG mengalami kebocoran sehingga tabung gas dapat meledak dan mengakibatkan kebakaran.

Perusahaan yang bergerak dalam pendistribusian sangat membutuhkan manajemen pemasaran agar perusahaan dapat terus bergerak dalam salah satunya adalah saluran distribusi untuk menyalurkan produk kepada konsumen, dengan adanya saluran distribusi maka perusahaan dapat meningkatkan minat beli konsumen dan juga mendapatkan rasa percaya konsumen. Oleh karena itu suatu perusahaan haruslah mampu bersaing dalam mendistribusikan produknya, sebuah rute pendistribusian dapat terjadi interaksi langsung antara konsumen dan produsen, tetapi bisa juga panjang dengan melalui perantara yang saling berhubungan, seperti grosir, distributor, pengecer. Setiap produk yang telah dibuat haruslah didistribusikan langsung kepada pelanggan atau konsumen, dengan cara apapun setiap produk harus disalurkan kepada konsumen menggunakan media distribusi ataupun menggunakan perantar melalui agen atau dikirim langsung kepada konsumen. Adapun jumlah pendistribusian tertinggi perusahaan terjadi pada bulan Juli, Oktober, dan Desember sebanyak 268.800 tabung, dan pendistribusian terendah pada bulan Februari, April, dan Juni sebanyak 221.760 
tabung. Permasalah yang terjadi pada perusahaan adalah kelangkan gas dari pihak pertamina, keterlambatan pengiriman gas dari stasiun pengisian bulk elpiji (SPBE).

Selain saluran distribusi, keunggulan produk tidak kalah penting untuk keberlangsungan suatu distributor gas $3 \mathrm{~kg}$, hal ini menjadi perhatian para konsumen apabila setiap produk yang di distribusikan oleh suatu distributor sering mengalami dan menerima pengembalian gas dari konsumen maka distributor tersebut akan memiliki citra yang tidak bagus bagi konsumen dan hal ini dapat membuat konsumen berpindah kepada pesaing. Apabila harapan pelanggan terhadap jasa yang diberikan perusahaan kepada pelanggan sesuai dengan yang diingikan, maka pelanggan tidak akan berpindah kepada pesaing dan berarti kualitas jasa yang diberikan baik, dengan kata lain perusahaan mendapatkan citra positif dan konsumen merasa puas dan cukup puas atas jasa yang diberikan oleh perusahaan. Dalam dunia bisnis kualitas adalah indikator terpenting agar perusahaan dapat terus bertahan dalah menghadapi persaingan, dengan adanya kesamaan kualitas antara perusahaan dengan para pesaing maka dapat dipastikan perusahaan dapat berkembang dengan baik dengan cara memperhatikan kepuasan pelanggan terus-menerus. Pada akhirnya setiap perusahaan akan mengetahui bahawa permasalahan kualitas bukanlah suatu hal yang dapat dianggap sebelah mata karena akan menjadi pertimbangan pelanggan untuk menggunakan jasa dari besarnya kualitas yang diberikan oleh perusahaan. Perusahaan memliki 5 truk yang siap mendistribusikan gas kepada pelanggan, setiap truk dapat mendisribuskan lebih dari 560 tabung setiap harinya. Semakin baik kualitas produk yang terdapat dalam suatu produk maka akan semakin menarik konsumen untuk melakukan pembelian. Permasalahan yang terjadi pada perushaan adalah gas yang mengalami kebocoran, berat gas kurang dari $3 \mathrm{~kg}$, kerusakan tabung gas sehingga membuat pelanggan kurang percaya kepada perusahaan dengan kualitas tabung gas yang diberikan.

Apabila manajemen suatu perusahaan telah bekerja dengan baik maka, keputusan konsumen melakukan pembelian akan semakin besar dan juga perusahaan akan mendapatkan keuntungan yang cukup untuk kegiatan operasional suatu perusahaan. Keputusan pembelian didasarkan pada penilaian yang dibentuk mengenai nilai pemasaran yang dilakukan pemasaran. Harapan konsumen didasarkan pada pembelian dimasa lalu, banyak perusahaan yang sukses saat ini karena berhasil memenuhi ekspetasi konsumen. Adapun perumusan masalah dalam penelitian ini adalah Bagaimana pengaruh saluran distribusi melalui keputusan pembelian pada PT. Tasya Gasindo Medan, Bagaimana pengaruh persediaan produk melalui keputusan pembelian pada PT. Tasya Gasindo Medan, Bagaimana pengaruh keunggulan produk melalui keputusan pembelian pada PT. Tasya Gasindo Medan

Persediaan produk suatu hal yang penting bagi perusahaan apabila persediaan produk tidak tercukupi untuk konsumen maka besar kemungkinan konsumen akan berpindah ke perusahaan lain. Persediaan produk dalam suatu perusahaan sangat diperlukan karena kegiatan operasional perusahaan tidak akan bekerja dengan baik bahkan tidak akan berjalan. Setiap perusahaan harus menjaga persediaan karena ini adalah salu satu faktor yang penting untuk mendapatkan keuntungan bagi perusahaan. Dengan demikian perusahaan perlu melakukan pengendalian persediaan agar dapatkan mempertahankan jumlah persediaan yang dibutuhkan pelanggan, mengontrol persedian merupakan fungsi manajerial yang sangat penting bagi perusahaan karena persediaan fisik yang ada dapat dihitung dalam investasi yang cukup berarti pada aktiva lancar suatu peruahaan, adapun fungsi dari persediaan bertujuan agar pendistribusian suatu 
jasa atau produk dapat berjalan dengan semaksimal mungkin sehigga mendapatkan kepuasan yang cukup berarti bagi perusahaan. Permasalah yang terjadi pada perusahaan adalah pihak pertamina memberi jatah kepada setiap agen, keterlambatan pendistribusian oleh pertamina kepada agen dan juga kelangkaan gas dari pihak pertamina, sedangkan persediaan tabung yang dimiliki oleh perusahaan hanya 3.760 tabung.

Oleh sebab itu, setiap penjualan yang dilakukan oleh perusahaan mengalami naik dan turun seperti padan bulan juni perusahaan mencatat mendapatkan hasil penjualan sekitar Rp. 3,240,847,784. Sedangkan penjualan tertinggi terdapat pada bulan desember perusahaan mencatat mendapatkan hasil penjualan sekitar Rp. 3,915,333,437. Berdasarkan latar belakang masalah dan fenomena diatas maka peneliti tertarik untuk melakukan penelitian pada perusahaan ini dengan judul "Pengaruh saluran distirbusi, keunggulan produk, persediaan produk melalui keputusan pembelian pada PT. Tasya Gasindo Medan."

\section{TINJAUAN PUSTAKA}

\section{Pengaruh saluran distribusi melalui keputusan pembelian}

Menurut Putri (2017:116) setiap perantara yang melakukan tugas membawa produk dan kepemilikannya lebih dekat ke pembeli akhir merupakan suatu tingkat saluran. Karena produsen dan konsumen akhir keduanya melakukan perjalanan, maka mereka merupakan bagian dari setiap saluran.

Menurut Sudaryono (2016: 220) faktor distribusi memberikan kemudahan kepada pada konsumen karena produk tersebut mudah untuk dibeli saat dibutuhkan.

Menurut Kotler dan Armstrong (2010 : 363) distribusi merupakan seperangkat organisasi yang saling bergantung satu sama lain yang dilibatkan dalam proses penyediaan suatu produk atau jasa untuk digunakan atau dikonsumsi oleh konsumen atauu pelanggan bisnis.

\section{Pengaruh keunggulan produk melalui keputusan pembelian}

Menurut Rusdiana (2014: 217) konsumen selalu mencari nilai yang dianggap paling tinggi dari beberapa produk atau jasa yang ada. Mereka membentuk harapan tentang nilai tersebut, dapat diukur besarnya tingkat kepuasan yang dimiliki konsumen. Menurut Djohan (2016: 31) kualitas dan harga, yang kemudian membentuk nilai pembeli sebagai dasar keputusan membeli setelah melewati pengaruh dari sikap orang lain dan faktor situasional yang tidak diantisipasi. Menurut kotler dan Armstrong (2017 :2) kualitas produk merupakan senjata strategis yang potensial untuk mengalahkan pesaing.

\section{Teori pengaruh persediaan Produk melalui keputusan pembelian}

Menurut Ardiprawiro (2015 : 111) ketidakmampuan menyediakan barang yang sudah dipesan sesuai waktunya akan mengakibatkan hilangnya kepercayaan konsumen. Dan bukan tidak mungkin akibatnya pelanggaan akan beralih ke perusahaan lain.

Menurut Rusdiana (2014 : 378) menyelesaikan sasaran yang berpotensi untuk memaksimalkan pelayanan pada efisiensi konsumen, memaksimalkan efisiensi pembelian pada produksi, meminimalkan investasi stok, memaksimalkan profit.

Menurut Utari (2014 : 138) kekurangan persediaan bahan baku dan kekurangan persediaan barang jadi akan mengakibatkan kesulitan memenuhi permintaan konsumen, 
sebaliknya jika terjadi kelebihan persedian, dapat mengakibatkan modal yang ditanamkan dalam persedian tersebut besar, biaya modalnya besar.

\section{Peneliti terdahulu}

Pradana (2016) dari penelitian yang dilakukan oleh peneliti terdahulu dapat diperoleh kesimpulan bahwa varibel kualitas produk secara parsial berpengaruh signifikan terhadap proses keputusan pembelian, variable harga secar parsial berpengaruh signifikan terhadap proses keputusan pembelian, variabel promosi secara parsial berpengaruh signifikan terhadap proses keputusan pembelian, variable saluran distribusi secara parsial berpengaruh signifikan terhadap proses keputusan pembelian, variabel citra merek secara parsial berpengaruh signifikan terhadap proses keputusan pembelian

Suryani (2019) dari penelitian yang dilakukan oleh peneliti terdahulu dapat diperoleh kesimpulan bahwa hasil pengujian hipotesis telah membuktikan terdapat pengaruh antara kualitas pelayanan dengan minat beli konsumen, pengujian menunjukan bahwa kualitas pelayanan memiliki pengaruh positif terhadap minat beli konsumen. hasil pengujian hipotesis telah membuktikan terdapat pengaruh antara persediaan barang dengan minat beli konsumen, pengujian menunjukan bahwa persediaan barang berpengaruh positif terhadap minat beli konsumen

Santika (2016) dari penelitian yang dilakukan oleh peneliti terdahulu dapat diperoleh kesimpulan bahwa faktor produk, faktor harga, faktor promosi dan factor distribusi berepengaruh positif fan signifikan terhadap keputusan pembelian bakpia di kota Yogyakarta. Hal didasarkan dari hasil uji $\mathrm{F}$ dimana $F_{\text {hitung }}>F_{\text {tabel }}(4-, 36>2,47)$.

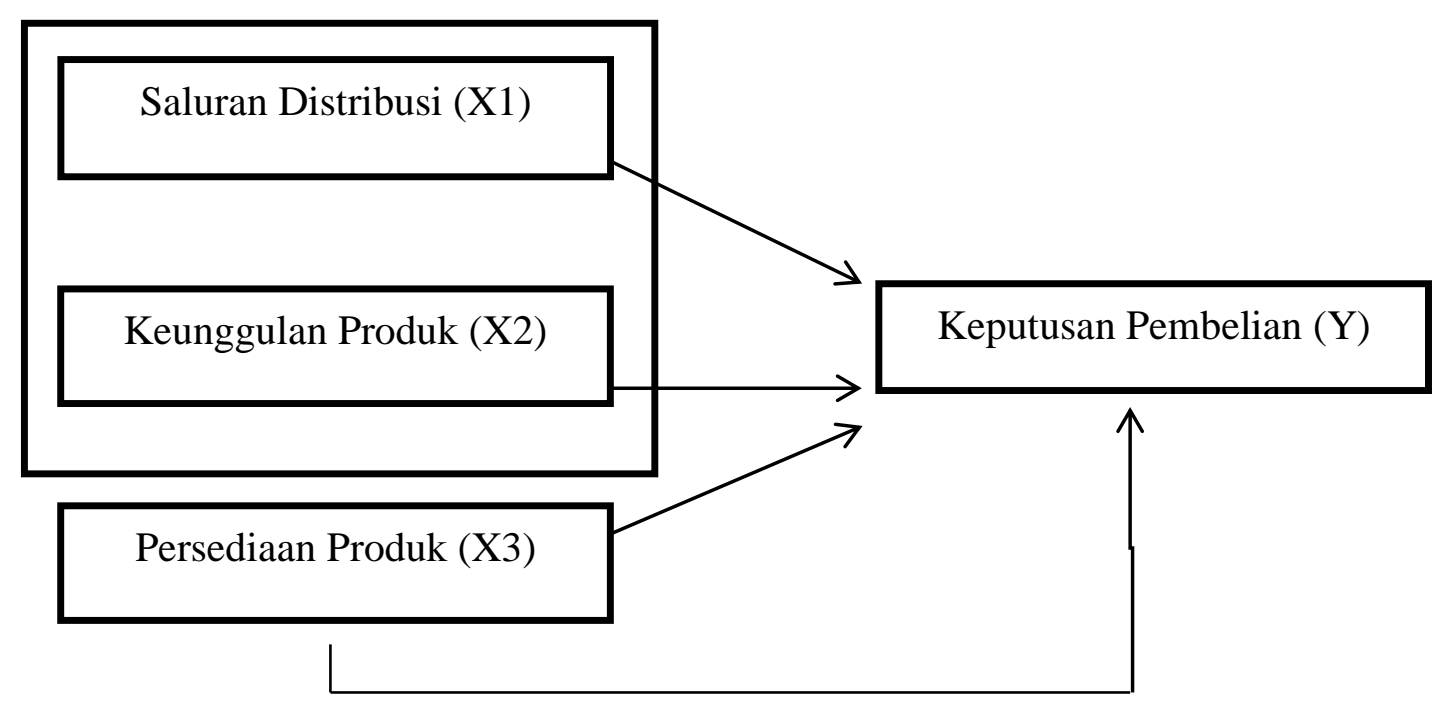

Gambar 1. Kerangka konseptual

\section{METODE}

Teknik Pengumpulam data dalam penelitian ini menggunakan teknik kuesioner dan wawancara yang bertujuan untuk mendapatkan data seberapa puas konsumen terhadap PT.Tasya Gasindo Medan, dan sebagai landasan teori-teori bagi sipeneliti.Teori-teori tersebut didapatkan melalui jurnal terdahulu, buku teks yang berkaitan dengan penelitian ini. Populasi dan sampel dalam penelitian ini adalah berjumlah 100 pelanggan selama di tahun 2019 pada PT. Tasya Gasindo Medan. 
Tabel 1. Identifikasi dan defenisi operasional variabel penelitian

\begin{tabular}{|c|c|c|c|}
\hline Variabel & Definisi & Indikator & Skala \\
\hline $\begin{array}{c}\text { Saluran } \\
\text { distribusi }\left(\mathrm{X}_{1}\right)\end{array}$ & $\begin{array}{l}\text { Menurut putri (2017: } 114) \text { rute } \\
\text { atau rangkaian perantara, baik } \\
\text { yang dikelola pemasar maupun } \\
\text { yang independen, dalam } \\
\text { menyampaikan produk dari } \\
\text { produsen sampai ke } \\
\text { konsumen. }\end{array}$ & $\begin{array}{l}\text { 1. Saluran distribusi atau } \\
\text { pemasaran. } \\
\text { 2. Cakupan pasar. } \\
\text { 3. Biaya. } \\
\text { 4. Kontrol. } \\
\text { 5. Konflik saluran. } \\
\text { Menurut Sudaryono } \\
\text { (2016:224) }\end{array}$ & Likert \\
\hline $\begin{array}{l}\text { Persediaan } \\
\text { produk }\left(\mathrm{X}_{2}\right)\end{array}$ & $\begin{array}{l}\text { Menurut Rusdiana (2014:374) } \\
\text { bahan atau barang yang } \\
\text { disimpan untuk memenuhi } \\
\text { tujuan tertentu,misalnya unutk } \\
\text { digunakan dalam proses } \\
\text { produksi atau perakitan, untuk } \\
\text { dijual kembali atau untuk suku } \\
\text { cadang. }\end{array}$ & $\begin{array}{l}\text { 1. Jumlah penjualan. } \\
\text { 2. Daya tahan dan faktor } \\
\text { mudahnya rusak barang. } \\
\text { 3. Kemudahaan pengadaan } \\
\text { kembali sediaan. } \\
\text { 4. Konsekuensi kehabisan } \\
\text { sedian suatu barang. } \\
\text { 5. Faktor harga beli. } \\
\text { Menurut Kasmir } \\
\text { (2010:138) }\end{array}$ & Likert \\
\hline $\begin{array}{l}\text { Keunggulan } \\
\operatorname{produk}\left(\mathrm{X}_{3}\right)\end{array}$ & $\begin{array}{l}\text { Menurut Rusdiana (2014:216) } \\
\text { kulitas dapat ditempatkan } \\
\text { sebagai alat yang sangat } \\
\text { ampuh dalam usaha } \\
\text { mempertahankan bisnis suatu } \\
\text { perusahaan. Dengan demikian, } \\
\text { kualitas dapat di pergunakan } \\
\text { untuk memenangkan } \\
\text { persaingan. }\end{array}$ & $\begin{array}{l}\text { 1.Bukti fisik } \\
\text { 2.Keandalan } \\
\text { 3.Ketanggapan } \\
\text { 4.Jaminan } \\
\text { 5.Empati } \\
\text { Menurut } \\
\text { Rusdiani(2014:218) }\end{array}$ & Likert \\
\hline $\begin{array}{c}\text { Keputusan } \\
\text { pembelian (Y) }\end{array}$ & $\begin{array}{l}\text { Menurut Sangji dan Sopiah } \\
\text { (2013:121) keputusan } \\
\text { pembelian adalah proses } \\
\text { pengambilan keputusan } \\
\text { konsumen melakukan } \\
\text { pembelian atau tidak terhadap } \\
\text { suatu produk atau jasa yang } \\
\text { ditawarkan oleh perusahaan }\end{array}$ & $\begin{array}{l}\text { 1. Kesadaran } \\
\text { 2. Minat } \\
\text { 3. Mencoba } \\
\text { 4. Empati } \\
\text { 5. Adopsi } \\
\text { Menurut Kotler dan } \\
\text { Armstrong (2010:184) }\end{array}$ & Likert \\
\hline
\end{tabular}

Sumber : Data diolah, 2020

\section{HASIL DAN PEMBAHASAN}

\section{Analisis statistik deskriptif}

Uji deskriptif merupakan teknik yang dilakukan dengan cara menggambarkan ciriciri seperti menunjukkan jumlah pengukuran $(\mathrm{N})$, nilai minimum, nilai maksimum, nilai rata-rata (Mean), standart deviasi (Std). Hasil pengujian yang telah dilakukan dapat dilihat pada tabel di bawah ini: 
Tabel 2. Analisis statistik deskriptif

\begin{tabular}{|c|c|c|c|c|c|c|}
\hline \multirow[b]{2}{*}{ Variabel } & \multirow[b]{2}{*}{$\begin{array}{c}\mathbf{N} \\
\text { Statistic }\end{array}$} & \multirow[b]{2}{*}{$\begin{array}{l}\text { Minimum } \\
\text { Statistic }\end{array}$} & \multirow[b]{2}{*}{$\begin{array}{c}\text { Maximum } \\
\text { Statistic }\end{array}$} & \multicolumn{2}{|c|}{ Mean } & \multirow{2}{*}{$\begin{array}{c}\text { Std. Deviation } \\
\text { Statistic }\end{array}$} \\
\hline & & & & Statistic & $\begin{array}{c}\text { Std. } \\
\text { Error }\end{array}$ & \\
\hline Saluran Distribusi & 100 & 10 & 42 & 33.10 & .538 & 5.381 \\
\hline $\begin{array}{l}\text { Keunggulan } \\
\text { Produk }\end{array}$ & 100 & 14 & 32 & 22.15 & .353 & 3.526 \\
\hline $\begin{array}{l}\text { Persediaan } \\
\text { Produk }\end{array}$ & 100 & 24 & 44 & 32.15 & .392 & 3.917 \\
\hline $\begin{array}{l}\text { Keputusan } \\
\text { Pembelian }\end{array}$ & 100 & 31 & 47 & 38.94 & .376 & 3.763 \\
\hline Valid N (listwise) & 100 & & & & & \\
\hline
\end{tabular}

Sumber : Data diolah, 2020

Pada Tabel 2 dapat dilihat bahwa deskriptif statistik menjelaskan bahwa masingmasing variabel memiliki nilai-nilai yang berbeda. seperti variabel saluran distribusi memiliki rata-rata sebesar 33.10 dengan std.deviationnya 5.381 dan juga nilai tertinggi sebesar 42.00 serta nilai terendah sebesar 10.00. Dan pada variabel keunggulan produk memiliki rata-rata sebesar 22.15 dengan std.deviationnya 3.526 dan juga nilai tertinggi sebesar 32.00 serta nilai terendah sebesar14.00.Pada variabel persediaan produk memiliki rata-rata sebesar 32.15 dengan std.deviationnya 3.917 dan juga nilai tertinggi sebesar44.00 serta nilai terendah sebesar 24.00. Pada variabel keputusan pembelian memiliki rata-rata sebesar 38.94 dengan std.deviationnya 3.763 dan juga nilai tertinggi sebesar 47.00 serta nilai terendah sebesar 31.00.

\section{Uji asumsi klasik}

Syarat dalam menggunakan model regresi linear berganda dengan metode ordinary least square (OLS) adalah terpenuhinya semua asmumsi klasik agar hasil pengujian tidak bersifat bias dan efisien (Best Linear Unbiased Estimator/BLUE).

\section{Uji normalitas}

Uji normalitas menunjukkan bahwa variabel dependen dan variabel independen dalam model regresi mempunyai distribusi normal atau tidak.Uji normalitas dapat dilakukan melalui dua pendekatan yaitu melalui grafik (histogram dan P-P Plot).untuk mendeteksi normalitas data dapat juga dilakukan dengan non-parametricstatistic dengan uji kolmogorv-sminorv (K-S). Jika sig $>0.05$ maka distribusi normal dan jika $<0,05$ maka distirbusi tidak normal

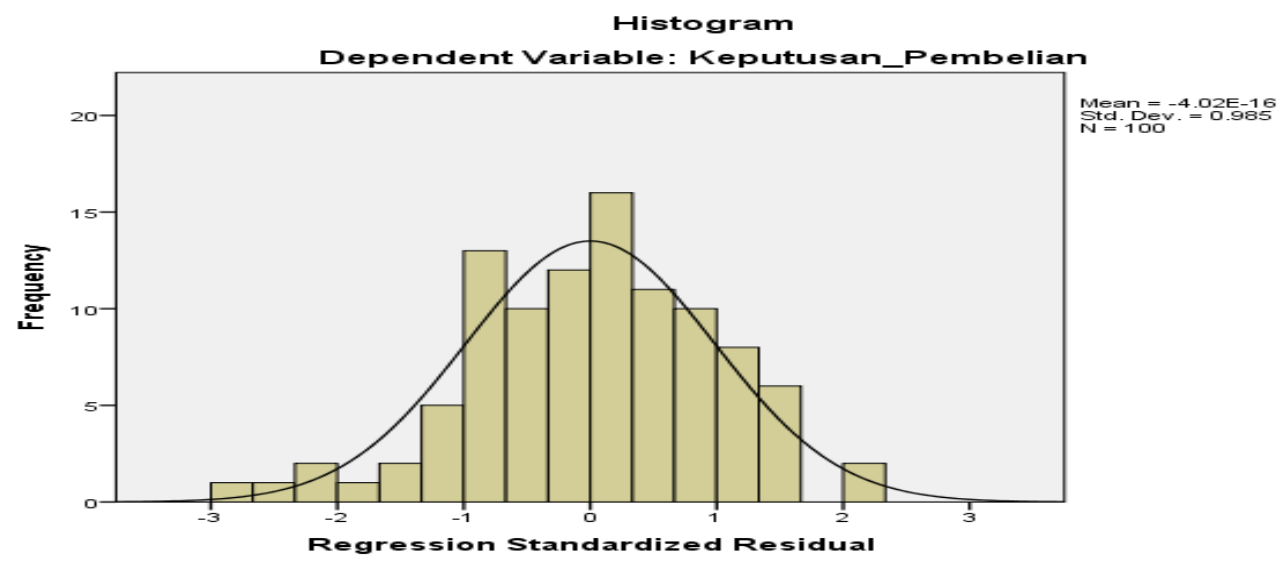

Gambar1.Histogram 
Berdasarkan Gambar 1. menunjukkan bahwa histogram pada gambar diatas menunjukkan pola distribusi normal karena grafik kecembungan seimbang ditengah, dan juga banyaknya angka disekitaran 0 maka dapat dinyatakan data berdistribusi secara normal. Demikian pula hasil uji normalitas dengan menggunakan grafik p-plot pada gambar di bawah ini :

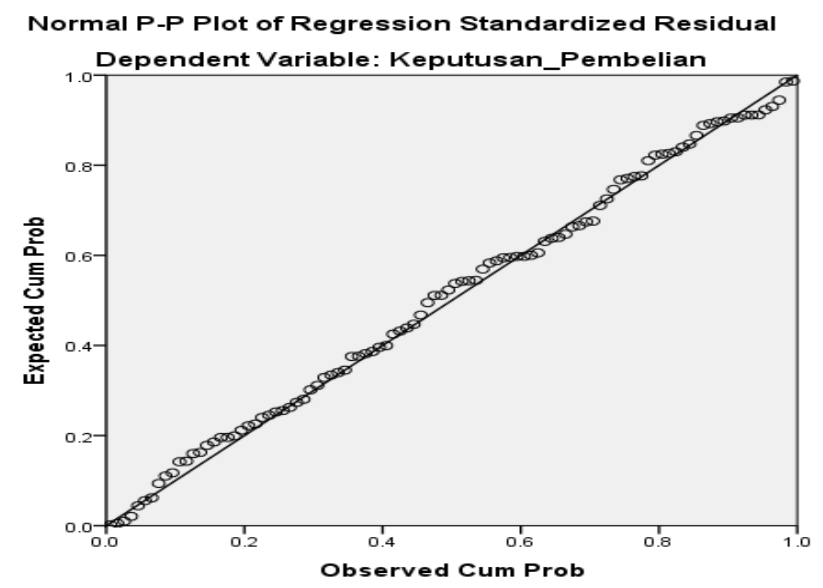

Gambar 2. Normalitas P-Plot

Pada Gambar 2. menunjukkan normalitas P-Plot menunjukkan bahwa data atau titik yang diperoleh menyebar disekitaran garis diagonal dan penyebarannya sebagian besar mengikuti arah garis diagonal. Sehingga dapat disimpulkan bahwa data ini berdistribusi normal atau lulus uji normalitas. Dan uji normalitas dalam penelitian ini menggunakan metode One-Sample Kolmogorov-Smirnov Test. Adapun hasil dari uji tersebut adalah sebagai berikut.

Tabel 3. Uji kolmogorov smirnov test

One-Sample Kolmogorov-Smirnov Test

\section{Unstandardized Residual}

\begin{tabular}{|c|c|c|}
\hline $\mathrm{N}$ & & 100 \\
\hline & Mean & $0 \mathrm{E}-7$ \\
\hline Normal Parameters ${ }^{\mathrm{a}, \mathrm{v}}$ & Std. Deviation & 3.43754125 \\
\hline Most Fytreme & Absolute & .041 \\
\hline $\begin{array}{l}\text { Most Extreme } \\
\text { Differences }\end{array}$ & Positive & .036 \\
\hline & Negative & -.041 \\
\hline Kolmogorov-Smirnov 2 & & .413 \\
\hline Asymp. Sig. (2-tailed) & & .996 \\
\hline
\end{tabular}

a. Test distribution is Normal.

b. Calculated from data.

Sumber: Data diolah, 2020

Pada Tabel 3, menunjukkan nilai signifikan 0,996 > 0,05. Dengan demikian dari hasil uji Kolmogorov Smirnov menunjukkan nilai residual data berdistribusi normal.

\section{Uji multikolinieritas}

Uji multikolinieritas bertujuan untuk menguji apakah model regresi di temukan adanya korelasi antar variabel bebas (independen). Jika nilai tolerance yang rendah sama dengan VIF tinggi (karena VIF = 1/tolerance) di pakai untuk menunjukan adanya 
multikolonieritas nilai tolerance $>0,10$ atau sama dengan nilai VIF $<10$. adapun hasil uji sebagai berikut:

Tabel 4.Uji multikolonieritas

\begin{tabular}{|c|c|c|c|c|c|c|c|c|}
\hline \multicolumn{9}{|c|}{ Coefficients $^{\mathbf{a}}$} \\
\hline & \multirow[t]{2}{*}{ Model } & \multicolumn{2}{|c|}{$\begin{array}{l}\text { Unstandardized } \\
\text { Coefficients }\end{array}$} & $\begin{array}{c}\text { Standardized } \\
\text { Coefficients }\end{array}$ & \multirow[t]{2}{*}{$\mathbf{t}$} & \multirow[t]{2}{*}{ Sig. } & \multicolumn{2}{|c|}{$\begin{array}{c}\text { Collinearity } \\
\text { Statistics }\end{array}$} \\
\hline & & B & Std. Error & Beta & & & Tolerance & VIF \\
\hline \multirow{4}{*}{1} & (Constant) & 24.887 & 3.650 & & 6.818 & .000 & & \\
\hline & $\begin{array}{l}\text { Saluran } \\
\text { Distribusi }\end{array}$ & .021 & .067 & 030 & .314 & .754 & .954 & 1.049 \\
\hline & $\begin{array}{l}\text { Keunggulan } \\
\text { Produk }\end{array}$ & .315 & .103 & 295 & 3.058 & .003 & .933 & 1.072 \\
\hline & $\begin{array}{l}\text { Persediaan } \\
\text { Produk }\end{array}$ & .198 & .095 & 207 & 2.091 & .039 & .891 & 1.123 \\
\hline
\end{tabular}

a. Dependent Variable: Keputusan pembelian

Sumber : Data diolah, 2020

Berdasarkan Tabel 4 dapat dilihat bahwa nilai tolerance untuk variabel saluran distribusi sebesar $(0,954)>0,10$ dan nilai VIF $(1,049)<10$ menunjukkan tidak adanya multikolinieritas. Nilai tolerance untuk variable keunggulan produk sebesar $(0,933)>$ 0,10 dan nilai VIF $(1,072)<10$ menunjukkan tidak adanya multikolinieritas. Nilai tolerance variable persediaan produk sebesar $(0,891)>0,10$ dan VIF $(1.123)<10$ menunjukkan tidak adanya multikolinieritas. Dapat disimpulkan bahwa data dinyatakan terbebas dari masalah Multikolinieritas atau lulus uji Multikolinieritas.

\section{Uji heteroskedastisitas}

Terdapat dua cara untuk menguji Heteroskedastisitas, uji ini sendiri bertujuan untuk menguji perbedaan variance residual suatu periode pengamatan ke periode pengamatan yang lain. Cara yang pertama untuk mendeteksi ada atau tidaknya heteroskedastisitas ialah dengan Scatterplot.

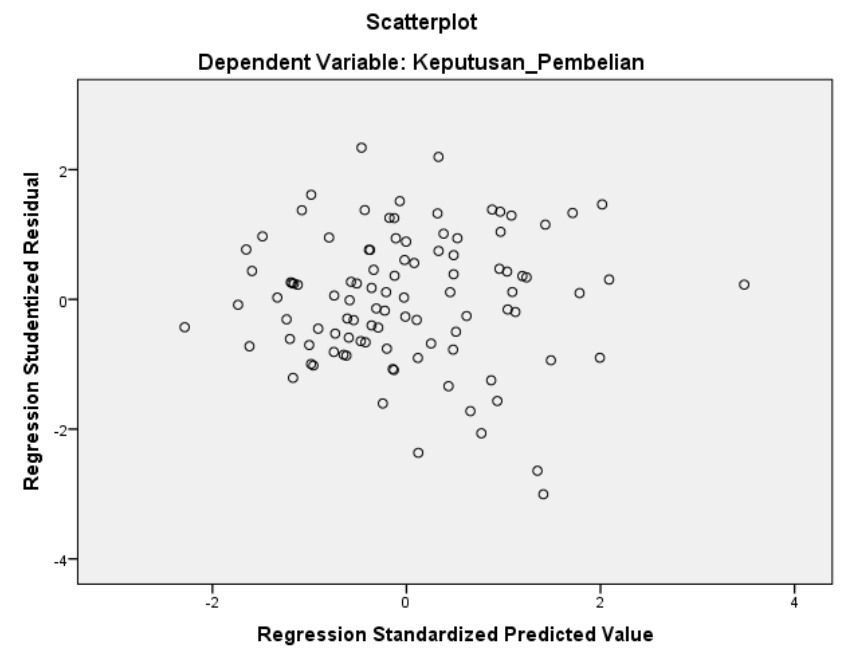

Gambar 3. Uji Heteroskedastisitas

Dilihat dari grafik menunjukkan titik-titik yang menyebar tidak membentuk pola tertentu dan tidak jelas, baik diatas maupun dibawah angka nol (0) pada sumbu Y, tidak berkumpul disatu tempat, sehingga dapat disimpulkan bahwa tidak terjadi 
heteroskedastisitas pada model regresi sehingga layak untuk dipakai. Dan dilihat dari hasil uji gletjer dibawah ini :

Tabel 5. Uji heteroskedastisitas

\begin{tabular}{|c|c|c|c|c|c|c|}
\hline \multicolumn{7}{|c|}{ Coefficients $^{\text {a }}$} \\
\hline & \multirow[t]{2}{*}{ Model } & \multicolumn{2}{|c|}{$\begin{array}{l}\text { Unstandardized } \\
\text { Coefficients }\end{array}$} & \multirow{2}{*}{$\begin{array}{c}\begin{array}{c}\text { Standardized } \\
\text { Coefficients }\end{array} \\
\text { Beta }\end{array}$} & \multirow[t]{2}{*}{$\mathbf{t}$} & \multirow[t]{2}{*}{ Sig. } \\
\hline & & B & Std. Error & & & \\
\hline \multirow{4}{*}{1} & (Constant) & .287 & 2.133 & & .135 & .893 \\
\hline & Saluran distribusi & -.015 & .039 & -.038 & -.374 & .709 \\
\hline & Keunggulan produk & .163 & .060 & .275 & 2.702 & .008 \\
\hline & Persedian produk & -.021 & .055 & -.040 & -.387 & .700 \\
\hline
\end{tabular}

a. Dependent Variable: ABS_RES2

Sumber: Data diolah, 2020

Berdasarkan uji glejser diatas diketahui nilai signifikansi variabel saluran distribusi sebesar 0,709>0,05 dengan demikian tidak terjadi heteroskedastisitas. Sementara, nilai signifikansi variabel keunggulan produk sebesar $0,008<0,05$ yang artinya terjadi heteroskedastisitas. Dan nilai signifikansi variable persediaan produk sebesar 0,700 > 0,05 artinya tidak terjadi heteroskedastisitas. Karena nilai signifikan dua variabel di atas lebih besar dari 0,05 maka dapat disimpulkan bahawa dua variabel tidak terjadi heteroskedastisitas, dan satu variable terjadi heteroskedastisitas

\section{Model analisis data penelitian}

\section{Model penelitian}

Uji regresi linier berganda di gunakan oleh peneliti, bila bermaksud meramalkan bagaiamana keadan (naik turunnya) variabel independen bila kedua atau lebih independen atau sebagai faktor kreditor dimanipulasi (dinaikkan nilainya).

Tabel 6. Model penelitian

\begin{tabular}{lccccc}
\multicolumn{1}{c}{ Model } & \multicolumn{2}{c}{ Coefficients $^{\mathbf{a}}$} \\
& Coefficients & $\begin{array}{c}\text { Standardized } \\
\text { Coefficients }\end{array}$ & t & Sig. \\
\cline { 2 - 5 } & $\mathbf{B}$ & Std. Error & Beta & & \\
\hline (Constant) & 24.887 & 3.650 & & 6.818 & .000 \\
Saluran distribusi & .021 & .067 & .030 & .314 & .754 \\
Keunggulan produk & .315 & .103 & .295 & 3.058 & .003 \\
Persediaan produk & .198 & .095 & .207 & 2.091 & .039 \\
\hline
\end{tabular}

a. Dependent Variable: Keputusan pembelian

Sumber: Data diolah, 2020

Hasil output SPSS tabel Coefficients maka persamaan regresinya adalah :

$$
\mathrm{Y}=\mathbf{2 4 , 8 8 7 + 0 , 0 2 1 \times 1 + 0 , 3 1 5 \times 2 + 0 , 1 9 8 \times 3 + e}
$$

Konstanta sebesar 24,887 menyatakan bahwa jika variabel saluran distribusi, keunggulan produk dan persediaan produk konstan maka variabel keputusan pembelian sebesar 24,887 satuan. Jika saluran distribusi meningkat satu satuan maka keputusan pembelian akan meningkat sebesar 0,021 satuan. Jika keunggulan produk meningkat 
satu satuan maka keputusan pembelian akan meningkat sebesar 10,315 satuan. Jika persediaan produk meningkat satu satuan keputusan pembelian akan meningkat sebesar 0,198 satuan

\section{Koefisien determinasi ( $\mathbf{R}^{\mathbf{2}}$ )}

Koefisien determinasi pada intinya mengukur seberapa jauh kemampuan model dalam menerapkan variasi variabel dependen. Nilai yang mendekati berarti variabelvariabel bebas memberikan hampir semua informasi yang dibutuhkan untuk memprediksi variabel terikat.

Tabel 7. Koefisien determinasi

\section{Model Summary}

\begin{tabular}{|c|c|c|c|c|}
\hline Model & $\mathbf{R}$ & R Square & $\begin{array}{l}\text { Adjusted R } \\
\text { Square }\end{array}$ & $\begin{array}{l}\text { Std. Error of the } \\
\text { Estimate }\end{array}$ \\
\hline 1 & $.407^{\mathrm{a}}$ & .165 & .139 & 3.491 \\
\hline
\end{tabular}

Hasil uji koefisien determinasi diperoleh nilai Adjusted $R$ Square sebesar 0,139 hal ini berarti $13,9 \%$ dari variasi variabel terikat yaitu Saluran Distribusi,Keunggulan produk dan Persediaan Produk . Sedangkan sisanya sebesar 86,1\% (100\% - 13,9\%) dijelaskan oleh variabel lainnya yang tidak diteliti pada penelitian ini.

\section{PENELITIAN DAN PEMBAHASAN}

\section{Pengujian hipotesis secara simultan (Uji F)}

Uji statistik F yaitu pengaruh simultan yang pada dasarnya digunakan untuk mengetahui apakah variabel independen secara bersama-sama atau simultan mempengaruhi variabel dependen.

Tabel 8. Uji simultan (uji F)

\begin{tabular}{|c|c|c|c|c|c|c|}
\hline \multicolumn{7}{|c|}{ ANOVA $^{a}$} \\
\hline & Model & Sum of Squares & df & $\begin{array}{l}\text { Mean } \\
\text { Square }\end{array}$ & $\mathbf{F}$ & Sig. \\
\hline \multirow{3}{*}{1} & Regression & 231.788 & 3 & 77.263 & 6.340 & $.001^{\mathrm{b}}$ \\
\hline & Residual & 1169.852 & 96 & 12.186 & & \\
\hline & Total & 1401.640 & 99 & & & \\
\hline
\end{tabular}

a. Dependent variable: Keputusan pembelian

b.Predictors: (constant), Persediaan produk, Saluran distribusi, Keunggulan produk

Sumber: Data diolah, 2020

Hasil uji ANOVA dengan analisis $\mathrm{F}$ (Fisher) diketahui nilai $\mathrm{F}_{\text {hitung }}$ sebesar (6.340) $>\mathrm{F}_{\text {tabel }}$ sebesar $(3.10)$ dengan nilai sig $0.001<0.05$ maka Ha diterima.Artinya Saluran Distribusi, Keunggulan produk dan Persediaan Produk berpengaruh positif dan signifikan terhadap Keputusan Pembelian.

\section{Pengujian hipotesis secara parsial (Uji t )}

Uji statistik t pada dasarnya menunjukan seberapa jauh pengaruh satu variabel penjelas/ independen secara individual dalam menerangkan variasi variabel dependen. 
Tabel 9. Uji parsial $(\mathrm{Uji}-\mathrm{t})$

\begin{tabular}{|c|c|c|c|c|c|c|}
\hline \multirow{3}{*}{\multicolumn{2}{|c|}{ Model }} & \multicolumn{3}{|c|}{ Coefficients $^{\text {a }}$} & \multirow{3}{*}{$\mathbf{t}$} & \multirow{3}{*}{ Sig. } \\
\hline & & \multicolumn{2}{|c|}{$\begin{array}{l}\text { Unstandardized } \\
\text { Coefficients }\end{array}$} & \multirow{2}{*}{$\begin{array}{c}\begin{array}{c}\text { Standardized } \\
\text { Coefficients }\end{array} \\
\text { Beta }\end{array}$} & & \\
\hline & & B & Std. Error & & & \\
\hline \multirow{4}{*}{1} & (Constant) & 24.887 & 3.650 & & 6.818 & .000 \\
\hline & $\begin{array}{l}\text { Saluran } \\
\text { Distribusi }\end{array}$ & .021 & .067 & .030 & .314 & .754 \\
\hline & $\begin{array}{l}\text { Keunggulan } \\
\text { Produk }\end{array}$ & .315 & .103 & .295 & 3.058 & .003 \\
\hline & $\begin{array}{l}\text { Persediaan } \\
\text { Produk }\end{array}$ & .198 & .095 & .207 & 2.091 & .039 \\
\hline
\end{tabular}

a. Dependent Variable: Keputusan Pembelian

Sumber: Data diolah, 2020

Hasil uji-t secara parsial diketahui bahwa: 1).Nilai $t_{\text {hitung }}$ Saluran Distribusi sebesar $0.314<\mathrm{t}_{\text {tabel }} 1,986$ kemudian nilai sig $0.754>0.05$ sehingga Ha ditolak, artinya Saluran Distribusi tidak berpengaruh dan tidak signifikan terhadap Keputusan Pembelian di PT. Tasya Gasindo Medan. 2).Nilai thitung Keunggulan produk sebesar $3.058>\mathrm{t}_{\text {tabel }} 1.986$ kemudian nilai sig $0.003<0.05$ sehingga Ha diterima, artinya Keunggulan produk berpengaruh signifikan terhadap Keputusan Pembelian di PT. Tasya Gasindo Medan. 3).Nilai thitung Persediaan Produk sebesar 2.091> $t_{\text {tabel }}$ 1,986 kemudian nilai sig $0.039<0.05$ maka Ha diterima, artinya Persediaan Produk berpengaruh signifikan terhadap Keputusan Pembelian di PT. Tasya Gasindo Medan.

\section{Pengaruh saluran distribusi terhadap keputusan pembelian di PT. Tasya Gasindo}

Berdasarkan hasil yang dilakukan oleh peneliti menujukan bahwa diketahui saluran distribusi tidak berpengaruh melalui keputusan pembelian yang diambil oleh pelanggan. Pada hasil penelitian dapat dilihat untuk nilai thitung saluran distribusi sebesar $0.314<\mathrm{t}_{\text {tabel }} 1,986$ kemudian nilai sig $0.754>0.05$ sehingga Ha ditolak, artinya saluran distribusi tidak berpengaruh dan tidak signifikan terhadap keputusan pembelian di PT. Tasya Gasindo Medan. Maka dapat dinyatakan saluran distribusi yang dilakukan oleh perusahaan kurang berpengaruh terhadap pembelian ulang yang akan dilakukan oleh pelanggan, adapun keterlambatan penyaluran distribusi terjadi dikarena pembagian jatah yang dilakukan oleh SPBE sehingga tidak semua perusahaan mendapatkan jumlah yang diinginkan. Adapun menurut para ahli Kotler dan Armstrong (2010:363), distribusi merupakan seperangkat organisasi yang saling bergantung satu sama lain yang dilibatkan dalam proses penyediaan suatu produk atau jasa untuk digunakan atau dikonsumsi oleh konsumen atau pelanggan bisnis dan hal ini tidak sejalan dengan hasil penelitian dimana saluran distribusi tidak berpengaruh dalam keputusan pembelian dikarenakan pembagian yang tidak merata dalam pendistribusiannya kepada pelanggan.

\section{Pengaruh keunggulan produk terhadap keputusan pembelian Di PT. Tasya Gasindo}

Berdasarkan hasil yang dilakukan oleh peneliti menunjukkan bahwa diketahui keunggulan produk berpengaruh melalui keputusan pembelian yang dilakukan oleh pelanggan. Nilai thitung keunggulan produk sebesar $3.058>t_{\text {tabel }} 1.986$ kemudian nilai sig 
$0.003<0.05$ sehingga Ha diterima yang artinya keunggulan produk berpengaruh signifikan terhadap keputusan pembelian di PT. Tasya Gasindo Medan. Maka dapat dinyatakan keunggulan produk sangat berpengaruh terhadap pembelian ulang yang dilakukan oleh pelanggan. Keunggulan produk adalah hal yang terutama dalam produk gas sehingga pelanggan merasa tenang dan senang apabila mengetahui bahwa gas yang dibeli adalah gas yang memiliki kualitas baik. Adapun menurut para ahli Menurut Rusdiana (2014:217) konsumen selalu mencari nilai yang dianggap paling tinggi dari beberapa produk atau jasa yang ada. Mereka membentuk harapan tentang nilai tersebut, dapat diukur besarnya tingkat kepuasan yang dimiliki konsumen.

\section{Pengaruh persediaan produk melalui keputusan pembelian di PT.Tasya Gasindo}

Berdasarkan hasil yang dilakukan oleh peneliti menujukan bahwa diketahui persediaan produk berpengaruh melalui keputusan pembelian yang dilakukan oleh

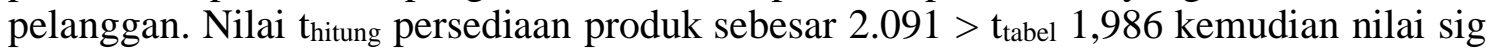
$0.039<0.05$ maka Ha diterima yang artinya persediaan produk berpengaruh signifikan terhadap keputusan pembelian di PT. Tasya Gasindo Medan. Maka dapat dinyatakan persediaan produk sangat berpengaruh terhadap pembelian ulang yang dilakukan oleh pelanggan, jika perusahaan menyediakan stok maka hal ini tidak akan membuat pelanggan berpindah kepada distributor lain dan juga membuat pelanggan tetap bertahan kepada perusahaan. Adapun menurut para ahli, Ardiprawiro (2015:111), ketidakmampuan menyediakan barang yang sudah dipesan sesuai waktunya akan mengakibatkan hilangnya kepercayaan konsumen. Dan bukan tidak mungkin akibatnya pelanggaan akan beralih ke perusahaan lain.

\section{KESIMPULAN DAN SARAN}

\section{Kesimpulan}

Berdasarkan hasil analisi dan pembahasan yang telah diuraikan maka dapat disimpulkan beberapa hal sebagai berikut: 1). Varibel saluran distribusi tidak berpengaruh positif dan tidak signifikan terhadap keputusan pembelian PT. Tasya Gasindo Medan. 2). Varibel keunggulan produk berpengaruh positif dan signifikan terhadap keputusan pembelian PT. Tasya Gasindo Medan. 3).Varibel persediaan produk berpengaruh positif dan signifikan terhadap keputusan pembelian pada PT. Tasya Gasindo Medan

\section{Saran}

Perusahaan disarakan agar lebih memaksimalkan saluran distribusi dan persedian agar pelanggan setia kepada perusahan dan tidak mencari agen yang baru dan juga perusahaan disarakan untuk memaksilkan laba yang di dapat sehingga persediaan yang dimiliki oleh perusahaan selalu berputar dan perusahaan memiliki citra positif dimata pelanggan.

Bagi peneliti selanjutnya disarankan untuk melanjutkan penelitian agar menghasilkan data yang lebih akurat dan lebih baik lagi apabila menambah variabelvaribel lain yang tidak diteliti dalam penelitian sehingga lebih bervariasi

\section{DAFTAR PUSTAKA}

Ardiprawiro. (2015). Dasar manajemen keuangan. Universitas Gunadarma: Jakarta. Djohan, A.J. (2016). Manajemen \& stretegi pembelian. Media Nusa Creative: Malang. Ghozali, Imam. (2016). Aplikasi analisis multivariete dengan program IBM SPSS 23 (Edisi 8). Cetakan Ke VII. Universitas Diponegoro: Semarang.

Kotler, Armstrong. (2010). Principles of marketing. upper saddle river: pearson. 
Putro, G.M.,\& Rizky, Fawzi E.P.(2016). Pengendalian persediaan Tabung Gas Lpg Untuk Meminimasi Total Biaya Persediaan Studi Kasus di PT Wina Wira Usaha Jaya. Jurnal OPSI(Optimasi Sistem Industri), 9(1), 33-41

Rusdiana. (2014). Manajemen operasi. Pustaka Setia: Bandung

Sangji, E.m., Sopiah. (2013). Prilaku konsumen: pendekatan praktis disertai: himpunan Jurnal Penelitian. Andi: Yogyakarta

Sudaryono. (2016). Manajemen pemasaran teori dan implementasi. Andi Offset: Yogyakarta.

Sugiyono. (2018). Metode penelitian kuantitatif, kualitatif dan R\&D. Alfabeta: Bandung.

Suryani. (2019). Pengaruh kualitas pelayanan dan persediaan barang terhadap minat beli konsumen di Jaya Cell Lamongan.

Tjiptono, Fandy. (2014). Pemasaran jasa - prinsip, penerapan, dan penelitian. Andi Offset: Yogyakarta

Utari, Ari, Darsono. (2014). Manajemen keuangan edisi revisi. Mitra Wacana Media: Jakarta.

Yusuf. (2015). Pengaruh kualitas produk, kebijakan harga, dan saluran distribusi terhadap kepuasan konsumen pembelian sperpart variasi dan pemasangan di CV Prima Ac: Banten

Zaenal, Mukarom. (2018). Manajemen pelayanan publik. Pustaka Setia: Bandung 
Jurnal Paradigma Ekonomika Vol.16.No.1, Januari -Maret 2021 ISSN: 2085-1960 (print); 2684 -7868 (online) 